\title{
Performa Peningkatan Lemak Dan Asam Lemak Linoleat Dari Daphnia Sp. Dengan Menggunakan Fermentasi Kotoran Burung Puyuh, Roti Afkir, Dan Ampas Tahu
}

\author{
Syaiful Anwar, Johannes Hutabarat, Vivi Endar Herawati* \\ Departemen Akuakultur \\ Jurusan Perikanan Fakultas Perikanan dan Ilmu Kelautan, Universitas Diponegoro \\ Jl. Prof. Soedarto, SH, Tembalang, Semarang. Jawa Tengah - 50275, Telp/Fax. +6224 7474698. \\ anshinvie@yahoo.com
}

\begin{abstract}
Daphnia sp. was natural feed which could adequate the needs of fish fry growth. Fats and fatty acids was main factor which very influenced the success of reproduction and live for hatched larva fish. Fats had important role as the main source. The lack of essencial fatty acid could impact the decrease of fish growth and reproduction. The purpose of this research were to found out the best treatments and the effect of fermented quail feces, bread waste, and tofu waste towards the growth, and increased fats and linoleic fatty acid from Daphnia sp..

The methods of this research was used experimental method and complete randomize design with 4 treatments and 3 repetitions, with density of 100 ind./litre. The treatments which used on this research were treatment A (50\% bread waste, $50 \%$ tofu waste, and $0 \%$ quail feces), treatment B (25\% bread waste, $50 \%$ tofu waste, and $25 \%$ quail feces), treatment C (50\% bread waste, $25 \%$ tofu waste, and $25 \%$ quail feces), and treatment C ( $25 \%$ bread waste, $25 \%$ tofu waste, and $50 \%$ quail feces) with total combination amount of 200 grams/litre. The data that observed were population of Daphnia sp., fatty acid value, and linoleic fatty acid value.

The result of this research showed that Daphnia sp. growth population was valued 502,22 ind/ml - 1949,44 $\mathrm{ind} / \mathrm{ml}$, whereas the increasing of fat value from $6,26 \%$ became $8,15 \%$ and linoleic fatty acid from $0,91 \%$ become $6,14 \%$. Acording to the research result could be concluded that the additition of fermented quail feces, and tofu waste gave differences towards the growth, with the fat value increased of Daphnia sp. was 1,89\% and linoleic fatty acid was $5,23 \%$ and the best treatment for growth and linoleic fatty acid value was the treatment C (50\% bread waste, $25 \%$ tofu waste, and $25 \%$ quail feces) and treatment A (50\% bread waste, $50 \%$ tofu waste, and $0 \%$ quail feces) for the fat value of Daphnia sp.
\end{abstract}

Keyword: Daphnia sp.; Fats; Linoleic Fatty Acid; Fermentation

\begin{abstract}
Abstrak
Daphnia sp. merupakan pakan alami yang mampu mencukupi kebutuhan untuk pertumbuhan benih ikan. Lemak dan asam lemak merupakan faktor yang sangat mempengaruhi keberhasilan reproduksi dan kelangsungan hidup larva yang baru menetas. Lemak berperan penting sebagai sumber energi. Kekurangan asam lemak esensial dapat menyebabkan penurunan reproduksi dan laju pertumbuhan ikan. Tujuan penelitian ini adalah untuk mengetahui perlakuan terbaik dan pengaruh dari pemberian fermentasi kotoran burung puyuh, roti afkir, dan ampas tahu terhadap pertumbuhan, peningkatan lemak, dan asam lemak linoleat dari Daphnia sp..

Metode penelitian ini menggunakan metode eksperimental dengan rancangan Acak Lengkap dengan 4 perlakuan dan pengulangan perhitungan sebanyak 3 kali, dengan padat tebar yaitu 100 individu/liter. Perlakuan yang digunakan dalam penelitian ini yaitu perlakuan A (50\% roti afkir, 50\% ampas tahu, dan $0 \%$ kotoran burung puyuh), perlakuan B (25\% roti afkir, 50\% ampas tahu, dan 25\% kotoran burung puyuh), perlakuan C (50\% roti afkir, $25 \%$ ampas tahu, dan $25 \%$ kotoran burung puyuh),dan perlakuan D (25\% roti afkir, $25 \%$ ampas tahu, dan $50 \%$ kotoran burung puyuh) dengan jumlah total kombinasi 200 gram/liter. Data yang diamati meliputi pertumbuhan populasi Daphnia sp., nilai kandungan lemak, dan asam lemak linoleat.

Hasil penelitian menunjukkan pertumbuhan populasi Daphnia sp. yaitu berkisar 502,22 ind/ml - 1949,44 ind/ml, sedangkan peningkatan nilai lemak dari $6,26 \%$ menjadi $8,15 \%$, dan asam lemak linoleat dari $0,91 \%$ menjadi $6,14 \%$. Berdasarkan hasil penelitian dapat disimpulkan bahwa pemberian fermentasi kotoran burung puyuh, roti afkir, dan ampas tahu berpengaruh terhadap pertumbuhan, dengan peningkatan lemak Daphnia sp. sebesar 1,89\% dan asam lemak linoleat yaitu sebesar 5,23\% dan perlakuan terbaik untuk pertumbuhan dan nilai asam lemak linoleat adalah
\end{abstract}


perlakuan C (50\% roti afkir, 25\% ampas tahu, dan 25\% kotoran burung puyuh), dan perlakuan A (50\% roti afkir, $50 \%$ ampas tahu, dan 0\% kotoran burung puyuh) untuk nilai lemak Daphnia sp.

Kata kunci : Daphnia sp.; Lemak; Asam Lemak Linoleat; Fermentasi

\section{PENDAHULUAN}

Salah satu permasalahan yang dihadapi dalam budidaya ikan khususnya tahap pembenihan adalah penyediaan pakan alami yang kontinyu dan berkualitas. Daphnia sp. merupakan pakan alami yang mampu mencukupi kebutuhan untuk pertumbuhan benih ikan maupun ikan hias (Utarini et al, 2012). Pakan alami merupakan pakan yang terbaik untuk budidaya ikan, hal ini karena mempunyai kandungan nutrisi yang tidak bisa digantikan oleh pakan buatan Daphnia sp. adalah zooplankton sebagai pakan alami terbaik untuk pemeliharaan larva ikan air tawar (Herawati dan Agus 2014).

Lemak selain sebagai sumber energi juga merupakan sumber asam lemak esensial. Fungsi lemak esensial anatara lain untuk menjaga intergritas membran sel, yaitu berfungsi untuk melindungi sel (Mokoginta et al, 2003). Kandungan nutrisi dari pakan alami Daphnia sp. terutama protein dan lemak sangat dibutuhkan oleh larva ikan untuk pertumbuhan dan sistem imunitasnya. Kandungan protein Daphnia sp. berkisasr 42-54\%, kandungan lemak berkisar $6,5-8 \%$ dari berat keringnya, dan asam lemak linoleat dan linolenatnya berkisar 7,5 dan 6,7 \% (Herawati dan Agus, 2014). Burung puyuh merupakan unggas yang diberi pakan yang berasal dari pabrik dan biasanya ransum tersebut banyak mengandung protein dan mineral. Hewan yang diberi ransum yang banyak mengandung protein dan mineral akan menghasilkan kotoran dan air kencing yang juga tinggi kandungan nitrogen dan mineral lainnya, dengan demikian apabila unsur nitrogen yang tersedia lebih banyak daripada unsur lainnya, dapat dihasilkan protein lebih banyak (Kusuma, 2012). Menurut Huri dan Syafriadiman (2007), kotoran puyuh memiliki kandungan protein sebesar $21 \%$, kandungan nitrogen sebesar $0,061 \%$, kandungan phospor 0,209\%, kandungan kalium sebesar $3,133 \%$. Roti afkir merupakan salah satu bahan penyusun ransum yang dapat dimanfaatkan sebagai sumber pakan bagi ternak, salah satunya burung puyuh yang mengandung sumber energi metabolisme yang tinggi. Hasil analisis proksimat membuktikan, roti afkir mengandung protein kasar $10,25 \%$, serat kasar $12,04 \%$, lemak kasar $13,42 \%$, kalsium $0,07 \%$, phospor $0,019 \%$, air $6,91 \%$ dan abu $0,80 \%$ serta energi bruto $4.217 \mathrm{kkal} / \mathrm{kg}$. Melihat kandungan energi metabolis yang dihitung dari Energi Bruto yaitu $2.952 \mathrm{kkal} / \mathrm{kg}$ (Widjastuti dan Endang, 2007) dan menurut Chalimi et al.,(2008) bahwa roti sisa pasar atau roti afkir memiliki kandungan berat kering 91,6\%, protein kering $10,9 \%$, kalsium $0,06 \%$ dan phospor $0,47 \%$. Menurut Asmoro et al., (2008) limbah ampas tahu memiliki kandungan barbagai bahan organik seperti nitrogen $0,27 \%$, phospor $228,85 \%$, kalium $0,29 \%$, dan protein 1,68\%. Menurut Mulia (2015), bahwa ampas tahu memiliki kadar air dan serat yang cukup tinggi, sehingga pemanfaatannya belum optimal dan masa simpannya relatif pendek. Namun, ampas tahu dapat dijadikan sumber protein. Prose fermentasi merupakan aplikasi metabolisme mikroba untuk mengubah bahan baku menjadi produk yang bernilai lebih tinggi, seperti asamasam organik, protein sel tunggal, biopolimer, dan antibiotika.

Tujuan dari penelitian ini adalah untuk mengetahui pengaruh pemberian fermentasi kotoran burung puyuh, roti afkir dan ampas tahu terhadap pertumbuhan, peningkatan lemak, dan asam lemak linoleat pada Daphnia sp., serta mengetahui perlakuan terbaik dari pemberian fermentasi kotoran burung puyuh, roti afkir dan ampas tahu terhadap pertumbuhan, peningkatan lemak, dan asam lemak linoleat pada Daphnia sp.. Hasil penelitian diharapkan dapat diaplikasikan kepada pembudidaya ikan air tawar tentang pentingnya lemak dan asam lemak linoleat serta penggunaan pupuk dengan dosis yang sesuai sebagai media untuk kultur Daphnia sp. Penelitian ini dilaksanakan pada tanggal 27 Juni 2016 hingga 13 September 2016 yang bertempat diSekertariat Asosiasi Pembudidaya dan Pedagang Ikan Hias Semarang (APPIHS), Poncol, Semarang. 


\section{BAHAN DAN METODE}

Hewan uji yang digunakan pada penelitian ini yaitu pakan alami berupa Daphnia sp. yang diperoleh dari alam dengan kepadatan penebaran yaitu $100 \mathrm{ind} / \mathrm{l}$. Dasar penebaran yang dilakukan berdasarkan penelitian yang dilakukan oleh Herawati et al., (2015) bahwa kepadatan penebaran Daphnia sp. sebanyak 100 ind/l. Wadah yang digunakan dalam kultur masal Daphnia sp. adalah bak beton sebanyak 4 buah dengan ukuran 2 x 1,2 x 0,5 m yang diisi air sebanyak 600 liter. Media yang digunakan dalam kultur Daphnia sp. berupa pupuk organik kombinasi dari kotoran burung puyuh, ampas tahu, dan roti afkir yang di fermentasi menggunakan bakteri probiotik. Pupuk organik yang sudah difermentasi selanjutnya dimasukan kedalam air media yang akan digunakan untuk kultur Daphnia sp..

Rancangan percobaan yang digunakan dalam penelitian ini adalah Rancangan Acak Lengkap (RAL) menggunakan 4 perlakuan dan penghitungan populasi diulang sebanyak 3 kali. Jumlah total kombinasi antara kotoran burung puyuh, ampas tahu, dan roti afkir yaitu $200 \mathrm{~g} / \mathrm{l}$. Perlakuan tersebut memodifikasi penelitian Herawati et al., (2016) dengan perlakuan terbaik pada 25\% kotoran burung puyuh, 50\% roti afkir, $25 \%$ ampas tahu. Perlakuan dalam penelitian adalah kombinasi pupuk organik dalam media kultur dengan dosis yang berbeda yaitu:

Perlakuan A : $0 \%$ kotoran burung puyuh, $50 \%$ ampas tahu dan $50 \%$ roti afkir;

Perlakuan B : $25 \%$ kotoran burung puyuh, $50 \%$ ampas tahu dan $25 \%$ roti afkir;

Perlakuan C : $25 \%$ kotoran burung puyuh, $25 \%$ ampas tahu dan $50 \%$ roti afkir;

Perlakuan D : $50 \%$ kotoran burung puyuh, $25 \%$ ampas tahu dan $25 \%$ roti afkir;

Tahapan sebelum dilakukan penebaran pupuk organik kedalam media kultur yaitu menyiapkan semua bahan, melakukan penimbangan bahan yang akan digunakan, dan melakukan analisa nutrien pupuk organik sebelum dan setelah fermentasi.

\section{HASIL DAN PEMBAHASAN}

Tabel 1. Kandungan nutrient pupuk organik sebelum fermentasi

\begin{tabular}{|c|c|c|c|c|c|}
\hline \multirow{2}{*}{ Parameter } & \multicolumn{4}{|c|}{ Hasil analisa sebelum fermentasi } & \multirow{2}{*}{ Metode uji } \\
\hline & A & $\mathrm{B}$ & $\mathrm{C}$ & $\mathrm{D}$ & \\
\hline Nitrogen $(\mathrm{N})$ & $1,54 \pm 0,05$ & $1,19 \pm 0,05$ & $2,19 \pm 0,03$ & $2,26 \pm 0,09$ & Kjeldhal \\
\hline Phosphor (P) & $0,19 \pm 0,03$ & $0,41 \pm 0,02$ & $0,23 \pm 0,08$ & $0,54 \pm 0,07$ & AQAC 958.01.2000 \\
\hline Kalium (K) & $0,39 \pm 0,02$ & $0,21 \pm 0,09$ & $0,13 \pm 0,03$ & $0,54 \pm 0,02$ & AQAC 958.01.2000 \\
\hline
\end{tabular}

Tabel 2. Kandungan nutrient pupuk organik sesudah fermentasi

\begin{tabular}{lccccll}
\hline \multirow{2}{*}{ Parameter } & \multicolumn{5}{c}{ Hasil analisa sesudah fermentasi } & \multirow{2}{*}{ Metode uji } \\
\cline { 2 - 5 } & A & B & C & \multicolumn{1}{c}{ D } & \\
\hline Nitrogen (N) & $2,74 \pm 0,05$ & $2,89 \pm 0,01$ & $3,99 \pm 0,03$ & $3,37 \pm 0,09$ & Kjeldhal \\
Phosphor (P) & $0,27 \pm 0,02$ & $1,41 \pm 0,07$ & $1,33 \pm 0,02$ & $1,74 \pm 0,092$ & AQAC 958.01.2000 \\
Kalium (K) & $0,69 \pm 0,09$ & $1,41 \pm 0,01$ & $2,34 \pm 0,03$ & $1,96 \pm 0,06$ & AQAC 958.01.2000 \\
\hline Sunnnnnn
\end{tabular}

Sumber: Herawati et al., 2016

\section{Kepadatan Popupasi Daphnia sp.}

Kepadatan populasi Daphnia sp. dihitung setiap 2 hari dengan mengambil Daphnia sp. pada 3 titik sampling paling padat sebanyak $1 \mathrm{ml}$ kemudian dilakukan perhitungan jumlah Daphnia sp. pada setiap titik sampling dan dilakukan 3 kali pengulangan pada setiap titik untuk mendapatkan data yang valid. 


\section{Kandungan Nutrisi}

Kandungan nutrisi dari hasil kultur Daphnia sp. yang diujikan yaitu kandungan lemak dan kandungan asam lemak linoleat. Pengujian sampel terlebih dahulu Daphnia sp. dikeringkan dengan suhu yang tidak terlalu tinggi yang bertujuan agar kandungan nutrisi lemak dan asam lemak linoleat Daphnia sp. tidak rusak.

\section{Kualitas air}

Pengukuran parameter kualitas air yang meliputi suhu, DO, dan $\mathrm{pH}$ dilakukan setiap hari. Pengukuran DO menggunakan DO meter, pengukuraan suhu menggunakan termometer dan pengukuran $\mathrm{pH}$ menggunakan $\mathrm{pH}$ tester. Pengontrolan $\mathrm{pH}$ air berkisar antara 7,5-8,0 apabila pH air berada dibawah 7,5 maka dilakukan penambahan kapur dolomit

\section{HASIL}

\section{Pertumbuhan populasi Daphnia sp.}

Hasil yang didapatkan dari kepadatan
populasi Daphnia sp. yang dikultur dengan

menggunakan fermentasi pupuk organik yaitu kotoran burung puyuh, ampas tahu, dan roti afkir didapatkan pola pertumbuhan. Hasil kepadatan populasi Daphnia sp. menunjukkan selama pemeliharaan membentuk kurva sigmoid yang terdiri dari fase adaptasi (lag phase), fase eksponensial, fase stasioner, dan fase kematian (death phase). Grafik pola pertumbuhan dari Daphnia sp. dapat dilihat pada Gambar 1. Sebagai berikut.

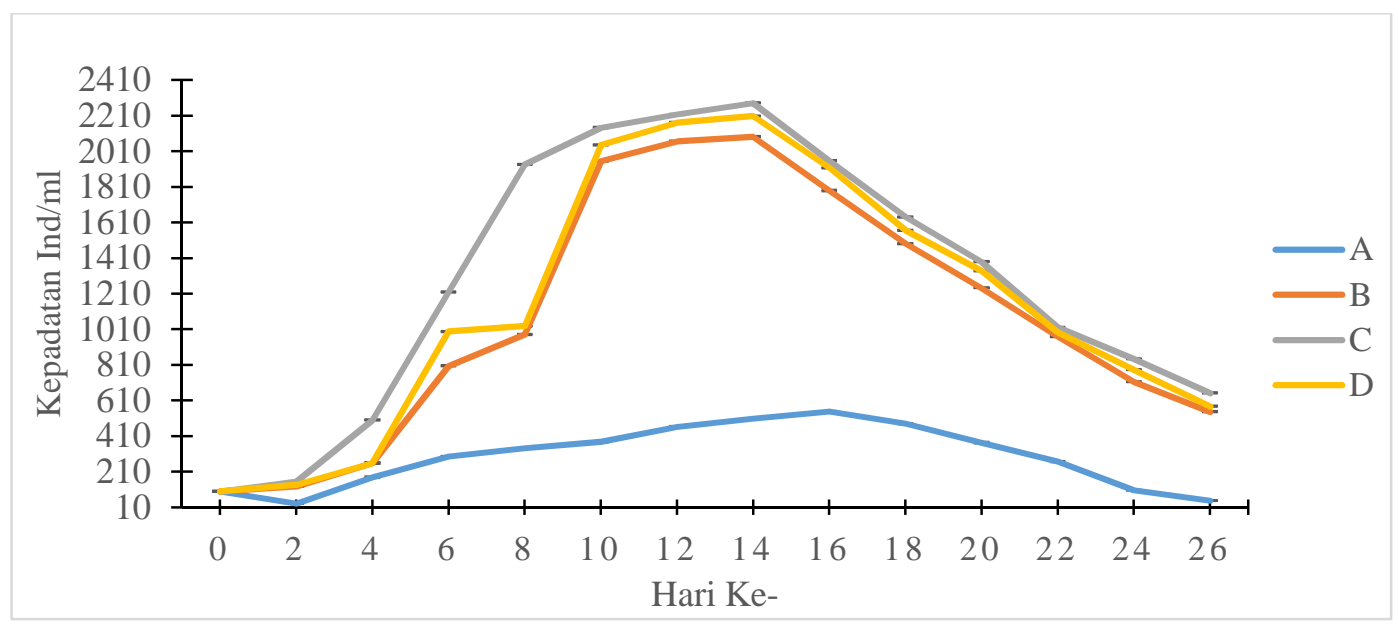

Gambar 1. Grafik Pola pertumbuhan populasi Daphnia sp.

Berdasarkan grafik pola pertumbuhan Daphnia sp. fase adaptasi (lag phase) terjadi pada hari ke-2 setelah penebaran dengan padat populasi tertinggi $615,00 \mathrm{ind} / \mathrm{ml}$ pada perlakuan yang menggunakan $50 \%$ roti afkir, $25 \%$ kotoran burung puyuh, dan $25 \%$ ampas tahu dan padat populasi terendah $159,33 \mathrm{ind} / \mathrm{ml}$ pada yang menggunakan $50 \%$ roti afkir, $50 \%$ ampas tahu, dan $0 \%$ kotoran burung puyuh. Fase eksponensial mulai terjadi pada hari ke- 4 sampai dengan hari ke-14 pada perlakuan 
yang menggunakan fermentasi $50 \%$ roti afkir, 50\% ampas tahu, dan $0 \%$ kotoran burung puyuh, sedangkan perlakuan yang menggunakan fermentasi $50 \%$ roti afkir, 25\% kotoran burung puyuh, dan $25 \%$ ampas tahu dan perlakuan $50 \%$ kotoran burung puyuh, 25\% roti afkir, dan 25\% ampas, dan perlakuan $50 \%$ ampas tahu, $25 \%$ roti afkir, dan $25 \%$ kotoran burung puyuh terjadi pada hari ke- 4 sampai dengan hari ke-12. Nilai padat populasi tertinggi $2088,22 \mathrm{ind} / \mathrm{ml}$ pada perlakuan Daphnia sp. yang menggunakan $50 \%$ roti afkir, $25 \%$ kotoran burung puyuh, dan $25 \%$ ampas tahu, dan padat populasi terendah yaitu $384,22 \mathrm{ind} / \mathrm{ml}$ pada perlakuan yang menggunakan $50 \%$ roti afkir, $50 \%$ ampas tahu, dan 0\% kotoran burung puyuh. Fase stasioner dari hasil penelitian menunjukkan terjadi pada hari ke- 14 pada perlakuan yang menggunakan fermentasi 50\% ampas tahu, 25\% roti afkir, dan 25\% kotoran burung puyuh, perlakuan yang menggunakan fermentasi $50 \%$ roti afkir, $25 \%$ kotoran burung puyuh, dan $25 \%$ ampas tahu dan $50 \%$ kotoran burung puyuh, $25 \%$ roti afkir, dan $25 \%$ ampas tahu dan terjadi pada hari ke-16 pada perlakuan yang menggunakan fermentasi 50\% roti afkir, 50\% ampas tahu dan 0\% kotoran burung puyuh. Nilai dengan padat populasi tertinggi yaitu
$1949,44 \mathrm{ind} / \mathrm{ml}$ pada perlakuan yang dengan menggunakan $50 \%$ roti afkir, $25 \%$ kotoran burung puyuh, dan $25 \%$ ampas tahu dan padat populasi terendah yaitu 502,22 ind/ml pada perlakuan yang menggunakan $50 \%$ roti afkir, $50 \%$ ampas tahu, dan $0 \%$ kotoran burung puyuh. Pada fase kematian (death phase) dari hasil penelitian menunjukkan terjadi pada hari ke- 18 dengan padat populasi tertinggi yaitu $1074,78 \mathrm{ind} / \mathrm{ml}$ pada perlakuan $50 \%$ roti afkir, 25\% ampas tahu, dan 25\% kotoran burung puyuh dan nilai terendah padat populasi yaitu 239,00 ind $/ \mathrm{ml}$ pada perlakuan yang menggunakan $50 \%$ roti afkir, $50 \%$ ampas tahu, dan $0 \%$ kotoran burung puyuh dengan selisih diantaranya yaitu $835,8 \mathrm{ind} / \mathrm{ml}$.

\section{Lemak Daphnia sp.}

Hasil uji proksimat kandungan lemak Daphnia sp. sebelum dilakukan perlakuan menggunakan fermentasi kotoran burung puyuh, roti afkir, dan ampas tahu yaitu sebesar 6,26\%. Sedangkan nilai kandungan lemak Daphnia sp. setelah dilakukan dengan menggunakan fermentasi kotoran burung puyuh, roti afkir, dan ampas tahu dapat dilihat pada Histogram Gambar 2. Sebagai berikut

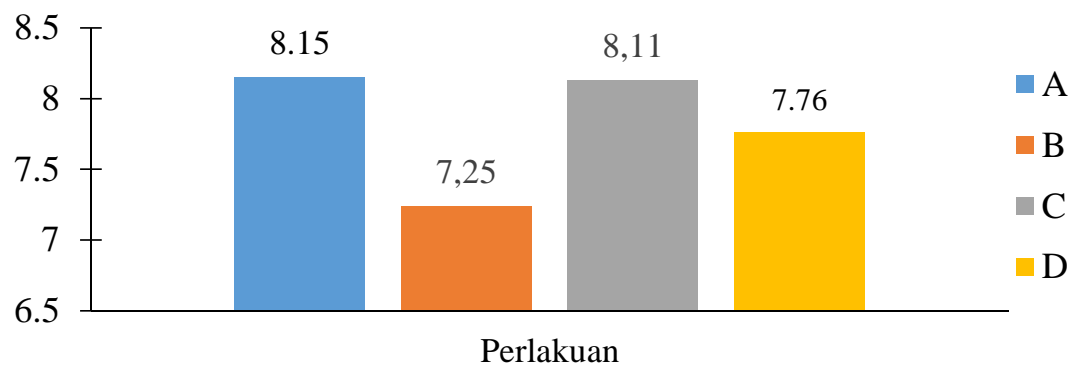

Gambar 2. Histogram kandungan lemak Daphnia sp

Berdasarkan nilai kandungan lemak dari histogram didapatkan nilai lemak paling tinggi yaitu pada perlakuan A yang menggunakan 50\% roti afkir, 50\% ampas tahu, dan $0 \%$ kotoran burung puyuh yaitu sebesar $8,15 \%$, sedangkan nilai terendah pada perlakuan B yang menggunakan 50\% ampas tahu, 25\% roti afkir, dan 25\% kotoran burung puyuh, dan yaitu sebesar $7,24 \%$. Selisih nilai pada 2 perlakuan tersebut yaitu sebesar 0,91 $\%$.

\section{Asam lemak linoleat Daphnia sp.}

Hasil kultur Daphnia sp. nilai kandungan asam lemak linoleat Daphnia sp. sebelum dilakukan perlakuan menggunakan fermentasi kotoran burung puyuh, roti afkir, dan ampas tahu yaitu sebesar $0,91 \%$. Sedangkan nilai kandungan 
asam lemak linoleat Daphnia sp. setelah dilakukan dengan menggunakan fermentasi kotoran burung puyuh, roti afkir, dan ampas tahu dapat dilihat pada Histogram Gambar 12. Sebagai berikut.

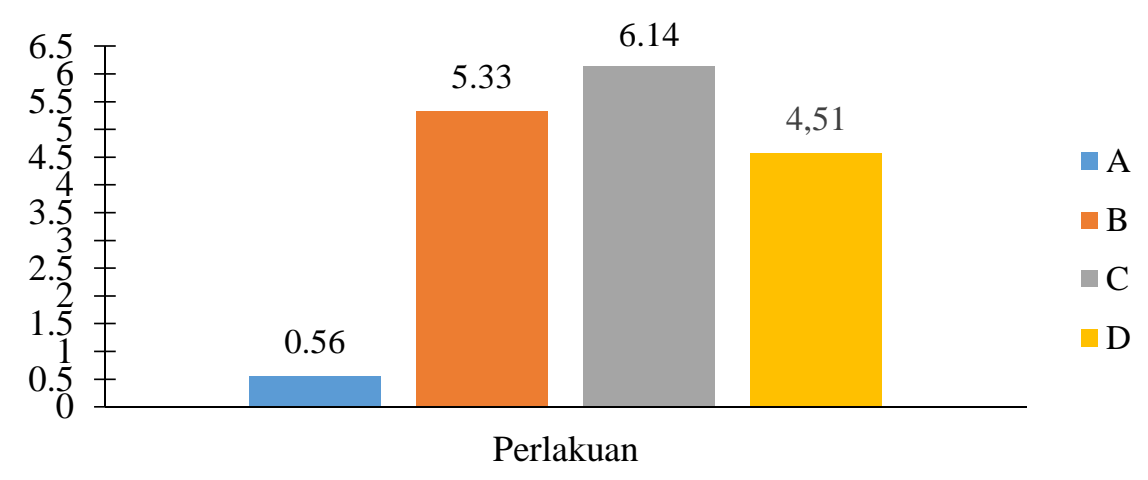

Gambar 3. Hitogram kandungan asam lemak linoleat Daphnia sp.

Berdasarkan hasil nilai dari kandungan asam lemak linoleat nilai yang paling tinggi yaitu pada perlakuan $\mathrm{C}$ yang menggunakan $50 \%$ roti afkir, $25 \%$ kotoran burung puyuh, dan $25 \%$ ampas tahu yaitu sebesar $6,14 \%$, sedangkan untuk nilai yang terendah yaitu pada perlakuan A yang menggunakan $50 \%$ roti afkir, $50 \%$ ampas tahu, dan $0 \%$ kotoran burung puyuh yaitu sebesar $0,56 \%$. Hasil antara 2 perlakuan tersebut didapatkan selisih yaitu sebesar 5,58\%.

\section{Kualitas air}

Parameter kualitas air yang diukur dalam wadah kultur Daphnia sp. yaitu pH, suhu, dan DO. Pengukran kualitas air dilakukan setiap hari. Hasil pengukuran kualitas air dapat dilihat pada Tabel 3. Sebagai berikut

Tabel 3. Hasil Pengukuran Kualitas Air

\begin{tabular}{|c|c|c|}
\hline Variabel & Kisaran & Referensi \\
\hline $\mathrm{DO}(\mathrm{mg} / \mathrm{L})$ & $3,2-3,5$ & $\begin{array}{l}2,7-4,5 \\
2015)\end{array}$ (Astika et al., \\
\hline $\mathrm{pH}$ & $7,3-8,6$ & 7,1- 7,5 (Sentosa, 2007) \\
\hline Suhu $\left({ }^{0} \mathrm{C}\right)$ & $26-31$ & $\begin{array}{l}22-31 \\
2009)\end{array}$ (Mubarak et al., \\
\hline
\end{tabular}

Hasil kualitas air yang didapatkan menunjukkan nilai yang baik untuk kultur massal Daphnia sp. Pengontrolan pH sangat penting untuk kelangsungan hidup Daphnia sp. karena $\mathrm{pH}$ harus diatas 7,5. Suhu dengan nilai 26 - 31 sedangkan nilai DO yaitu antara $3,2-3,5$.

\section{Pertumbuhan populasi Daphnia sp.}

Tinggi padat populasi pada fase adaptasi (lag phase) dari nilai tertinggi yang didapatkan sebesar $615,00 \mathrm{ind} / \mathrm{ml}$ diduga karena media kultur yang digunakan dalam penelitian sesuai dengan media kultur Daphnia sp. dialamnya. Hal ini sesuai menurut pendapat Izzah et al., (2014) bahwa waktu lag phase menunjukan lamanya adaptasi Daphnia sp. karena terjadinya penyesuaian terhadap media kultur dan kepekatan dalam media kultur mempengaruhi cepat atau lambat nya pertumbuhan Daphnia sp.. Laju pertumbuhan pada fase adaptasi proses pertumbuhannya belum terlalu meningkat karena pada fase ini Daphnia sp. masih menyesuaikan atau beradaptasi dengan lingkungan media kulturnya dan selanjutnya akan bereproduksi. Hal ini sesuai dengan pendapat Mubarak et al., (2009), menyatakan bahwa lama pencapaian puncak populasi adalah waktu antara awal kultur sampai puncak populasi sedangkan lama puncak populasi adalah waktu yang dibutuhkan saat populasi berada di puncak atau kepadatan relatif konstan. Populasi Daphnia sp. pada awal kultur dan hari ke-1, jumlah populasinya belum mengalami penambahan karena masih dalam tahap adaptasi terhadap lingkungan kultur. Setelah hari ke-2 populasi meningkat karena mulai terjadi partenogenesis yang menghasilkan anakan baru dengan cepat sampai mencapai puncak populasi. 
Salah satu faktor yang mempengaruhi populasi Daphnia sp. yaitu pakan.

Fase eksponensial pada penelitian ini didapatkan hasil tertinggi yaitu 2088,22 ind/ml tingginya nilai yang didapatkan ini diduga karena pakan yang berupa fitoplankton dalam media kultur mencukupi kebutuhan dari Daphnia sp. sehingga kepadatan dari populasi Daphnia sp. meningkat sangat cepat. Menurut Wibowo (2014), menyatakan bahwa semakin tinggi populasi fitoplankton yang ada dalam media budidaya maka ketersediaan pakan bagi Daphnia sp. semakin melimpah sehingga mencukupi kebutuhan energi untuk pertumbuhan Daphnia sp. yang ditandai dengan peningkatan populasi. Dalam kondisi pakan yang cukup, Daphnia muda (juvenil) akan tumbuh dan berganti kulit hingga menjadi individu dewasa dan berreproduksi secara parthenogenesis, sehingga terjadi penambahan individu menjadi beberapa kali lipat. Semakin meningkatnya populasi fitoplankton yang ada dalam media budidaya maka ketersediaan pakan bagi Daphnia sp. mencukupi sehingga pertumbuhan populasi Daphnia sp. juga meningkat. Menurut Darmawan (2014), peningkatan pertumbuhan populasi Daphnia sp. terjadi karena pada saat sebelum mencapai puncak, konsentrasi pakan yang terdapat dalam media lebih banyak dari kebutuhan maintenance (jumlah pakan yang tidak berpengaruh terhadap pertumbuhan) dari Daphnia sp. Kelebihan energi inilah yang kemudian dimanfaatkan Daphnia sp. untuk tumbuh dan berkembang biak. Daphnia sp. mulai berkembang biak pada umur lima hari dan selanjutnya akan bereproduksi setiap selang waktu satu setengah hari.

Fase stasioner adalah fase puncak pertumbuhan populasi, terjadi dalam waktu singkat dan selanjutnya akan mengalami penurunan yang akan mengalami kematian massal atau menuju ke fase kematian (death phase). Fase stasioner tertinggi didapatkan nilai sebesar 1949,44 ind/ml pada perlakuan C (50\% roti afkir, $25 \%$ ampas tahu, $25 \%$ kotoran burung puyuh) terjadi pada hari ke-14, sedangkan nilai terendah pada perlakuan A $(50 \%$ roti afkir, $50 \%$ ampas tahu, $0 \%$ kotoran burung puyuh) terjadi pada hari ke-16 sebesar 502,22 ind $/ \mathrm{ml}$. Perbedaan fase stasioner ini diduga karena pada saat menuju fase stasioner pemanfaatan fermentasi bahan organik dalam media kultur mengalami perbedaan. Pada perlakuan yang menggunakan kotoran burung puyuh fase stasioner terjadi pada hari ke-14 berbeda dengan perlakuan yang tidak menggunakan kotoran burung puyuh yang terjadi pada hari ke-16. Kotoran burung puyuh adalah termasuk kotoran ternak yang dapat berfungsi untuk sumber nutrisi yang akan berguna untuk media tumbuhnya pakan yaitu berupa fitoplankton dan akan bermanfaat untuk pakan dari Daphnia sp. Akan tetapi fase stasioner ini hanya berlangsung singkat karena akan mengalami fase kematian. Hal ini juga sesuai dengan pendapat Zahidah (2012), menyatakan bahwa tingginya kepadatan populasi Daphnia sp. saat mencapai puncak populasi menunjukkan bahwa populasi tersebut memiliki laju pertumbuhan yang lebih tinggi dibanding laju mortalitasnya. Laju pertumbuhan dan laju mortalitas populasi Daphnia sp. ini tidak terlepas dari fungsi pakan. Pakan bagi Daphnia sp. selain berupa fitoplankton, dapat pula berupa partikel organik tersuspensi serta bakteri. Daphnia sp. memerlukan nutrisi bagi pertumbuhannya. Nutrisi ini dapat berasal dari banyak sumber, diantara dari bahan organik tersuspensi dan bakteri yang diperoleh dari pupuk yang ditambahkan ke dalam media kultur, pupuk yang sering digunakan adalah pupuk organik yang berasal dari kotoran ternak. Proses penguraian (dekomposisi) pupuk organik ini akan menumbuhkan bakteri yang pada gilirannya akan dimanfaatkan sebagai pakan bagi Daphnia sp.

Fase kematian (death phase) dari hasil nilai tertinggi didapatkan nilai yaitu sebesar 1074,78 $\mathrm{ind} / \mathrm{ml}$ dan terjadi pada hari ke-18 fase kematian ini diduga terjadi karena nutrien dan pakan dalam media kultur sudah mengalami penurunan sehingga Daphnia sp. saling bersaing dalam mencari makan selain itu juga reproduksinya juga menurun dan kualitas air yang sebelumnya masih layak pakai menjadi tidak layak pakai mengakibatkan Daphnia sp. mengalami fase kematian. Menurut pendapat Astika et al., (2015), menyatakan bahwa peningkatan dan penurunan populasi Daphnia sp. selama pemeliharaan dipengaruhi oleh ketersediaan fitoplankton yang terdapat dalam media budidaya Daphnia sp. dan faktor kualitas air sangat berperan dalam pertumbuhan Daphnia sp. Dan hal ini juga sesuai dengan pendapat Izzah et al., (2014), fase kematian terjadi karena adanya penurunan nutrisi 
dalam media kultur. Berkurangnya nutrisi dalam media menyebabkan kematian pada Daphnia sp. yang tidak mendapatkan makanan. Sedangkan pada fase akhir budidaya Daphnia sp. mengalami penurunan jumlah populasi, hal ini diduga disebabkan oleh jumlah nutrien dalam media kultur telah berkurang karena telah dimanfaatkan oleh fitoplankton (Wibowo, 2014). Sedangkan menurut pendapat Umainana et al., (2012), menyatakan bahwa fase kematian disebabkan oleh beberapa faktor diantaranya adalah temperatur tinggi, kurangnya nutrisi dalam perairan, perubahan $\mathrm{pH}$, kontaminasi, serta berkurangnya proses fotosintesis. Ketersediaan nutrisi yang semakin berkurang setiap hari akan menyebabkan kematian bagi bakteri sehingga dengan adanya toksik yang dihasilkan dari kematian ini juga akan berpengaruh terhadap kehidupan Daphnia sp..

Faktor pakan yang merupakan faktor dari pertumbuhan Daphnia sp. didapatkan nilai kepadatan fitoplankton pada tiap perlakuan yaitu pada perlakuan yang menggunakan fermentasi 50\% roti afkir, $50 \%$ ampas tahu, dan $0 \%$ kotoran burung puyuh yaitu sebesar $13428 \mathrm{sel} / \mathrm{ml}$, pada perlakuan yang menggunakan fermentasi $50 \%$ ampas tahu, $25 \%$ roti afkir, dan $25 \%$ kotoran burung puyuh didapatkan hasil yaitu $47401 \mathrm{sel} / \mathrm{ml}$, sedangkan perlakuan yang menggunakan fermentasi $50 \%$ roti afkir, $25 \%$ kotoran burung puyuh, dan $25 \%$ ampas tahu didapatkan hasil yaitu $52135 \mathrm{sel} / \mathrm{ml}$, dan perlakuan yang menggunakan fermentasi $50 \%$ kotoran burung puyuh, 25\% roti afkir, dan 25\% ampas tahu didapatkan nilai yaitu $50450 \mathrm{sel} / \mathrm{ml}$. Nilai kepadatan fitoplankton dari Daphnia sp. didapatkan nilai tertinggi yaitu $52135 \mathrm{sel} / \mathrm{ml}$ dan nilai terendah yaitu $13428 \mathrm{sel} / \mathrm{ml}$, dengan nilai selisih diantaranya yaitu sebesar $38707 \mathrm{sel} / \mathrm{ml}$. Kepadatan fitoplankton yang semakin banyak menunjukkan laju pertumbuhan Daphnia sp. semakin cepat meningkat. Berdasarkan fitoplankton yang didapatkan dari 3 fitoplankton yaitu Clorophyceae, Synedra, dan Oschillatoria tertinggi adalah jenis Clorophyceae yaitu jenis dari famili Chlorophyta, hal ini diduga karena warna airnya yang berwarna hijau yang banyak mengandung klorofil dan kebanyakan fitoplankton tersebut hidup pada ikan air tawar. Menurut pendapat Pamukas (2011), menyatakan bahwa untuk pupuk organik yang menggunakan kotoran puyuh jumlah spesies terbanyak dijumpai pada divisi Chlorophyta, hal ini terlihat dengan warna permukaan air pada saat penelitian berwarna hijau. Chlorophyta merupakan fitoplankton yang banyak ditemukan di perairan tawar. Umumnya Chlorophyta paling banyak dijumpai di perairan tawar dan di dalam air yang terlihat berwarna hijau karena Chlorophyta banyak mengandung klorofil. Chlorophyta dapat berkembang dengan pemberian pupuk organik dan anorganik serta merupakan produser primer yang dapat dimanfaatkan langsung oleh zooplankton, larva dan benih ikan seperti ikan tambakan. Mikro alga dari divisi Chlorophyta berperan penting di perairan tawar, terutama sebagai pakan alami yang dapat secara langsung dikonsumsi oleh ikan herbivora dan juga sebagai produsen primer. Kelimpahan fitoplankton di suatu perairan juga dipengaruhi oleh berbagai faktor seperti suhu, nutrien, cahaya matahari, $\mathrm{pH}$, oksigen terlarut, dan karbondioksida bebas. Peningkatan kelimpahan fitoplankton akan diikuti dengan peningkatan kelimpahan zooplankton, yang makanan utamanya adalah fitoplankton

\section{Lemak Daphnia sp.}

Hasil yang didapatkan pada uji proksimat dari kultur Daphnia sp. didapatkan nilai kandungan lemak sebelum dilakukan perlakuan yaitu sebesar $6,26 \%$. Sedangkan nilai tertinggi dari kandungan lemak yang sudah diberi perlakuan dari nilai tertinggi yaitu sebesar $8,15 \%$ pada perlakuan yang menggunakan $50 \%$ roti afkir, 50\% ampas tahu, dan $0 \%$ kotoran burung puyuh, sedangkan nilai terendah yaitu sebesar 7,25\% pada perlakuan yang menggunakan $50 \%$ ampas tahu, $25 \%$ roti afkir, dan $25 \%$ kotoran burung puyuh dengan selisihnya yaitu sebesar 0,9\%. Peningkatan lemak Daphnia sp. tanpa perlakuan dengan menggunakan perlakuan menggunakan kotoran burung puyuh, roti afkir, dan ampas tahu didapatkan selisih yaitu sebesar 1,89\% dari nilai tertinngi yang menggunakan perlakuan $50 \%$ roti afkir, $50 \%$ ampas tahu, dan $0 \%$ kotoran burung puyuh. Sedangkan dengan perlakuan yang terendah yaitu menggunakan $50 \%$ ampas tahu, 25\% roti afkir, dan 25\% kotoran burung puyuh didapatkan hasil selisih antara lemak Daphnia sp. tanpa perlakuan yaitu sebesar $0,99 \%$. Peningkatan lemak dengan hasil tersebut sudah baik untuk kebutuhan larva ikan. Menurut pendapat Pangkey (2009), menyatakan bahwa pada Daphnia sp. 
dewasa mengandung lemak yang lebih tinggi dibandingan pada juvenil yaitu sekitar $20-27 \%$; serta $4-6 \%$ pada juvenil. Dilihat dari nilai dari yang didapat lemak dalam Daphnia sp. tersebut masih bagus untuk proses pertumbuhan dan sebagai pakan alami ikan. Dari hasil nilai lemak yang didapat dari nilai tertinggi sebesar $8,15 \%$ dan terendah sebesar $7,25 \%$, dan tanpa perlakuan yaitu sebesar $6,26 \%$, hasil tersebut masih rendah karena dalam penelitian Mokoginta et al., (2003), nilai lemak yang didapatkan yaitu sebesar 13,52\%. Namun nilai lemak yang didapatkan masih tinggi karena dalam penelitian Herawati dan Agus (2014), nilai kandungan lemak tertinggi yaitu 7,56\%. Tingginya kandungan protein dan rendahnya kandungan lemak dikarenakan nutrient yang ada dalam media kultur Daphnia sp. tersebut, dimana semakin tinggi kandungan nitrat dan fosfat maka semakin tinggi kandungan proteinnya dan semakin rendah kandungan lipidnya. Berdasarkan hasil yang didapatkan nilai lemak pada perlakuan dengan nilai tertinggi (50\% roti afkir, 50\% ampas tahu, 25\% kotoran burung puyuh) dan terendah (50\% ampas tahu, $25 \%$ roti afkir, $25 \%$ kotoran burung puyuh) ini diduga dipengaruhi oleh kandungan lemak dalam roti afkir, dilihat dari dosisnya yang berbeda pada pemakaian roti afkirnya, pada perlakuan dengan nilai tertinggi menggunakan $50 \%$ roti afkir sedangkan perlakuan dengan nilai rendah menggunakan dosis roti afkir sebanyak $25 \%$ dan dilihat dari perlakuan yang menggunakan $50 \%$ roti afkir, 25\% kotoran burung puyuh, 25\% ampas tahu dengan perlakuan dengan nilai tertinggi (50\% roti afkir, 50\% ampas tahu, 25\% kotoran burung puyuh) menggunakan dosis roti afkir 50\% didapatkan nilai yang didapatkan hampir sama yaitu $8,11 \%$ dan $8,15 \%$ dan selisihnya yaitu sebesar $0,04 \%$. Hal ini membuktikan bahwa roti afkir berpengaruh terhadap nilai kandungan lemak dan selain itu kandungan proksimat lemak dalam roti afkir tinggi dibandingkan dengan kandungan protein. Proses pemanfaatan dari pupuk organik tersbut yang kaya akan kandungan lemak tersebut adalah oleh fitoplankton dan sisa bahan organik tersebut yang sudah hancur yang diduga akan menyebabkan kandungan lemak dalam tubuh Daphnia sp. akan meningkat karena disebabkan fitoplankton dan sisa bahan organik yang sudah hancur tersebut yang dimakan mengandung lemak yang tinggi selain itu juga Daphnia sp. karena sifatnya non selective filter feeder atau memakan partikel tersuspensi yang sesuai dengan bukaan mulutnya. Analisis proksimat roti afkir menurut pendapat Widjastuti dan Endang (2007), roti afkir merupakan salah satu bahan penyusun ransum yang dapat dimanfaatkan sebagai sumber pakan bagi ternak, salah satunya burung puyuh yang mengandung sumber energi metabolisme yang tinggi. Hasil analisis proksimat membuktikan, roti afkir mengandung protein kasar $10,25 \%$, serat kasar $12,04 \%$, lemak kasar $13,42 \%$, kalsium $0,07 \%$, phospor $0,019 \%$, air $6,91 \%$ dan abu $0,80 \%$ serta energi bruto $4.217 \mathrm{kkal} / \mathrm{kg}$. Melihat kandungan energi metabolis yang dihitung dari Energi Bruto yaitu $2.952 \mathrm{kkal} / \mathrm{kg}$ dan menurut Chalimi et al., (2009), bahwa roti sisa pasar atau roti afkir memiliki kandungan berat kering 91,6\%, protein kering $10,9 \%$, kalsium $0,06 \%$ dan phospor $0,47 \%$. Hal ini menunjukkan bahwa roti afkir berpengaruh terhadap kandungan nilai lemak dan dibandingkan kandungan nilai protein nilai lemak lebih tinggi dalam roti afkir.

\section{Asam lemak linoleat Daphnia sp.}

Berdasarkan nilai kandungan asam lemak linoleat Daphnia sp. tanpa perlakuan didapatkan hasil yaitu sebesar $0,91 \%$. Sedangkan untuk nilai kandungan asam lemak linoleat yang menggunakan perlakuan didapatkan hasil tertinggi dan terendah yaitu sebesar 6,14\% yang menggunakan bahan 50\% roti afkir, 25\% kotoran burung puyuh, dan 25\% ampas tahu, sedangkan nilai terendahnya yaitu sebesar $0,56 \%$ yang menggunakan bahan $50 \%$ roti afkir, 50\% ampas tahu, dan 0\% kotoran burung puyuh. Selisih antara tertinggi dengan Daphnia sp. tanpa perlakuan yaitu sebesar $5,23 \%$, sedangkan untuk nilai terendah masih tinggi nilai lemak Daphnia sp. tanpa perlakuan, hal ini diduga karena perlakuannya $0 \%$ kotoran burung puyuh. Akan tetapi hasil yang didapatkan sudah baik untuk kebutuhan dari larva ikan. Menurut pendapat dari Pratiwi et al., (2009), bahwa asam lemak linoleat merupakan sintesis asam lemak omega 6 dan selain itu juga berperan sebagai substrat untuk memproduksi atau menghasilkan asam lemak linolenat yang merupakan sintesis asam lemak omega 3. Asam lemak linoleat akan berkurang karena asam lemak linoleat juga digunakan untuk memproduksi asam lemak lain dalam proses metabolis seperti asam lemak linolenat omega 3. 
Kekurangan asam lemak linoleat akan menyebabkan laju pertumbuhan melambat yang sesuai dengan penelitian dari Utomo et al., (2009), ikan tidak dapat mensintesis sendiri asam lemak linoleat (18:2n-6) dan asam linolenat (18:2n3), sehingga untuk memenuhi kebutuhannya perlu disuplai dari pakan. Kekurangan asam lemak esensial (Essential Fatty Acid = EFA) dapat menyebabkan penurunan reproduksi dan laju pertumbuhan ikan dan berdasarkan hasil yang didapatkan menunjukkan masih rendah dibandingkan dengan penelitian Herawati dan Agus, (2014), bahwa kandungan asam lemak linoleatnya berkisar 7,5\%. Akan tetapi dari hasil tertinggi maupun terendah yang didapat asam lemak linoleat masih sangat dibutuhkan untuk pertumbuhan larva ikan karena dalam penelitian Mokoginta et al., (2003), yang menyatakan bahwa juvenil ikan nila, Oreochromis niloticus membutuhkan 0,5\% asam lemak linoleat pakan untuk menghasilkan pertumbuhan yang baik. Adanya perbedaan kebiasaan makan antara larva dan ikan dewasa kemungkinan akan menyebabkan perbedaan kebutuhan asam lemak. Menurut Utomo et al., (2009), kebutuhan asam lemak berbeda untuk setiap jenis ikan sesuai dengan habitat dan lingkungannya. Ikan air tawar biasanya lebih banyak membutuhkan asam lemak n-6 (linoleat) daripada asam lemak n-3 (linolenat) atau campuran asam lemak n-6 (linoleat) dan n-3 (linolenat), sedangkan ikan laut lebih membutuhkan asam lemak n-3 (linolenat) kisaran kebutuhan asam lemak n-3 (linolenat) dan n-6 (linoleat) secara umum adalah antara 0,5-2,5\%. Hal ini dapat disimpulkan bahwa nilai asam lemak linoleat yang didapatkan pada penelitian ini masih layak untuk dikonsumsi oleh larva ikan.

Nilai dari asam lemak linoleat dari proses kultur Daphnia sp. yang menggunakan perlakuan didapatkan nilai tertinggi dan nilai terendah yaitu sebesar $6,14 \%$ dan $0,56 \%$ dengan selisih diantaranya yaitu sebesar $5,58 \%$, nilai asam lemak linoleat paling tinggi dari perlakuan yang menggunakan bahan $50 \%$ roti afkir, 25\% kotoran burung puyuh, dan $25 \%$ ampas tahu, sedangkan nilai terendah didapatkan dari perlakuan yang menggunakan bahan 50\% roti afkir, 50\% ampas tahu, dan 0\% kotoran burung puyuh. Diantara 4 perlakuan tersebut nilai asam lemak linoleat pada perlakuan A, B, C, dan D adalah 0,56\%, 5,33\%, $6,14 \%$, dan $4,51 \%$. Pada perlakuan $\mathrm{A}(50 \%$ roti afkir, 50\% ampas tahu, dan 0\% kotoran burung puyuh) nilai asam lemak linoleatnya rendah dibandingkan perlakuan B (50\% ampas tahu, 25\% roti afkir, dan $25 \%$ kotoran burung puyuh), C (50\% roti afkir, $25 \%$ kotoran burung puyuh, dan $25 \%$ ampas tahu), dan D (50\% kotoran burung puyuh, $25 \%$ roti afkir, dan $25 \%$ ampas tahu) ini diduga karena dosis kotoran burung puyuh pada perlakuan A $0 \%$ dibandingkan dengan perlakuan lainnya yang masih menggunakan dosis kotoran burung puyuh karena diduga kotoran burung puyuh kaya akan asam lemak linoleat yang didapatkan dari makanannya. Proses pemanfaatan pupuk organik tersebut akan dimanfaatkan terlebih dahulu oleh fitoplankton dan sisa bahan organik yang sudah hancur yang akan sebagai pakan dari Daphnia sp., sehingga akan masuk dalam tubuh Daphnia sp. tersebut karena sifat dari Daphnia sp. yang non selective filter feeder atau memakan partikel tersuspensi yang sesuai dengan bukaan mulutnya. Hal ini sesuai dengan pendapat Yusefi (2011), bahwa asam linoleat dan asam linolenat adalah prekursor dalam sintesis PUFA. Asam linoleat diproduksi dari tanaman dan secara khusus banyak dikandung pada seed oil. Walaupun alam memproduksi asam linoleat setara dengan asam linolenat, namun dapat ditemukan beberapa cadangan makanan. Hewan tidak dapat memproduksi asam linoleat, namun makanannya kaya asam lemak, dan manusia mendapatkan asam linoleat dalam daging. Asam linoleat berperan sebagai prekursor untuk produksi asam lemak esensial arakhidonat. Hal ini menunjukkan kotoran burung puyuh tiap perlakuan berpengaruh terhadap kandungan asam lemak linoleat walaupun hewan tidak bisa memproduksi asam lemak linoleat tetapi dari makanannya kaya akan asam lemak linoleat dan akan masuk dalam tubuh hewan tersebut terutama pada dagingnya.

\section{Kualitas air}

Kualitas air yang didapatkan pada kultur Daphnia sp. pada DO yaitu didapatkan nilai 3,2 $3,5 \mathrm{mg} / \mathrm{L}$, sedangkan untuk nilai $\mathrm{pH}$ didapatkan nilai yaitu sebesar 7,3 - 8,6 dan nilai suhu yaitu sebesar $26^{\circ} \mathrm{C}-31^{\circ} \mathrm{C}$. Nilai yang didapatkan tersebut sudah layak dalam budidaya Daphnia sp. Menurut Astika et al., (2015), menyatakan bahwa kualitas air 
yang optimal untuk tumbuh dan berkembang Daphnia sp. yaitu berkisar antara $22-32^{\circ} \mathrm{C}, \mathrm{DO}>$ 3,5 ppm, pH 6,0 - 8,0 , dan Amoniak 0,35 - 0,61. Menurut Darmawan (2014), menyatakan bahwa konsentrasi oksigen terlarut pada media budidaya memberikan pengaruh terhadap tingkat penyaringan dan fungsi hemoglobin Daphnia sp. Pada konsentrasi minimal $(<3,5 \mathrm{mg} / \mathrm{l})$, oksigen terlarut akan memberikan dampak yang nyata terhadap sistem reproduksi Daphnia sp. baik jumlah anakan maupun waktu pertama kali menghasilkan anakan. Menurut pendapat Mubarak et al., (2009), menyatakan bahwa perlakuan pemberian dolomit, $\mathrm{pH}$ selama pemeliharaan berada pada kisaran optimum pertumbuhan Daphnia sp. yaitu 7,1-7,5 dan temperatur yang baik bagi pertumbuhan dan reproduksi Daphnia sp. berkisar antara $22^{\circ} \mathrm{C}-31^{\circ} \mathrm{C}$. Sedangkan menurut pendapat Darmawan (2014), Daphnia sp. dapat tumbuh dan berkembang biak pada suhu $24^{\circ} \mathrm{C}-$ $28^{\circ} \mathrm{C}$ dan di luar kisaran tersebut Daphnia sp. akan cenderung pada kondisi dorman. Budidaya secara massal Daphnia sp. akan tumbuh secara optimal pada suhu $25^{\circ} \mathrm{C}$.

\section{KESIMPULAN DAN SARAN Kesimpulan}

Kesimpulan yang dapat diambil berdasarkan hasil penelitian yang telah dilakukan adalah sebagai berikut:

Pemberian kombinasi fermentasi kotoran burung puyuh, roti afkir, dan ampas tahu dengan dosis yang berbeda dalam media kultur memberikan pengaruh terhadap pertumbuhan dengan kepadatannya yaitu berkisar 502,22 ind/ml - 1949,44 ind/ml, dengan kandungan lemak tanpa perlakuan yaitu sebesar 6,26\%, dan kandungan lemak yang menggunakan perlakuan yaitu sebesar $7,25 \%-8,15 \%$ dan kandungan asam lemak linoleat tanpa perlakuan yaitu sebesar $0,91 \%$, dan setelah menggunakan perlakuan yaitu sebesar $0,56 \%$ 6,14\% pada Daphnia sp.

Perlakuan $\mathrm{C}$ dengan kombinasi fermentasi $25 \%$ kotoran burung puyuh, $25 \%$ ampas tahu dan $50 \%$ roti afkir merupakan perlakuan terbaik untuk pertumbuhan Daphnia sp. yang menghasilkan jumlah kepadatan populasi yang tinggi dan asam lemak linoleat pada Daphnia sp., dengan kepadatannya yaitu sebesar 1949,44 ind/ml dengan titik puncaknya (fase stasioner) yaitu pada hari ke14 dan nilai kandungan asam lemak linoleatnya sebelum perlakuan yaitu sebesar $0,91 \%$, dan setelah perlakuan yaitu sebesar $6,14 \%$. Sedangkan untuk nilai lemak sebelum perlakuan yaitu sebesar $6,26 \%$, dan yang menggunakan perlakuan nilai lemak paling terbaik adalah pada perlakuan A dengan kombinasi fermentasi 50\% roti afkir, 50\% ampas tahu, 25\% kotoran burung puyuh yaitu sebesar 8 , $15 \%$.

\section{Saran}

Berdasarkan penelitian yang telah dilakukan, saran yang dapat disampaikan adalah pemberian kombinasi fermentasi $25 \%$ kotoran burung puyuh, $25 \%$ ampas tahu dan $50 \%$ roti afkir merupakan dosis yang dianjurkan untuk mendapatkan kepadatan populsai Daphnia sp. yang tinggi dan kandungan lemak dan asam lemak linoleatnya.

\section{UCAPAN TERIMA KASIH}

Terima kasih penulis ucapkan kepada Dr. Vivi Endar Herawati S.Pi., M.Si yang telah membantu dalam penyewaan tempat untuk penelitian ini, Bapak Edi Irianto yang telah membantu selama penelitian berlangsung dan semua pihak yang telah membantu mulai dari persiapan dan terlaksananya penelitian sampai terselesaikannya penelitian ini.

\section{DAFTAR PUSTAKA}

Asmoro, Y., Suranto, D. Sutoyo. 2008. Pemanfaatan Limbah Tahu Untuk Peningkatan Hasil Tanaman Petsai (Brassica chinensis). Program Biosains, Universitas Sebelas Maret. Surakarta. Bioteknologi 5 (2): 51-55

Astika, Glycine, Henni Wijayanti, Siti Hudaidah. 2015. Penambahan Fermentasi Urine Sapi Sebagai Sumber Nutrien Dalam Budidaya Daphnia sp. Jurusan Budidaya Perairan Fakultas Pertanian. Universitas Lampung. Seminar Nasional Sains dan Teknologi VI, 596-606 hlm.

Chalimi, K. A., Rochim, E. Purbowati, Soedarsono, E. Rianto, dan A. Purnomoadi. 2009. Kelayakan Roti Sisa Pasar Sebagai Pakan Alternatif Berdasar Pemanfaatan Kecernaan 
Energi dan Parameter Darah Pada Sapi Peranakan Ongole. Seminar Nasional Peternakan dan Veteriner, 100-106 hlm.

Darmawan, J. 2014. Pertumbuhan Populasi Daphnia sp. Pada Media Budidaya Dengan Penambahan Air Buangan Budidaya Ikan Lele Dumbo. Berita Biologi. Balai Penelitian Pemuliaan Ikan, Sukamandi Subang. Jawa Barat, 57-63 hlm.

Herawati, V.E., M. Agus. 2014. Analisis Pertumbuhan Dan Kelulushidupan Larva Lele (Clarias gariepenus) Yang Diberi Pakan Daphnia sp. Hasil Kultur Massal Menggunakan Pupuk Organik Difermentasi. Program Studi Budidaya Perairan, Jurusan Perikanan, Fakultas Perikanan dan Ilmu Kelautan, Universitas Diponegoro. Semarang. Journal of Aquaculture and Technology, (26): 1-11

Herawati, V.E., Johannes H., Pinandoyo, Ocky K.R. 2015. Growth and Survival Rate of Tilapia (Oreochromis niloticus) Larvae Fed by Daphnia magna Cultured With Organic Fertilizer Resulted From Probiotic Bacteria Fermentation. HAYATI Journal of Biosciences. (30): 1-5

Herawati, V. E., Ristiawan A. N., Johannes H., Ocky K. R. 2016. Profile of Amino Acids, Fatty Acids, Proximate Composition And Growth Performance Tubifex Culture With Different Animal Wastes And Probiotic Bacteria. AACL Bioflux. 9 (3). DIPA. 023.05.02.

Huri, E. dan Syafriadiman. 2007. Jenis dan Kelimpahan Zooplankton dengan Pemberian Dosis Pupuk Kotoran Burung Puyuh yang Berbeda. J. Berkala Perikanan Terubuk. 35(1): 1-19.

Izzah, N. Suminto, dan Vivi E. H. 2014. Pengaruh Bahan Organik Bekatul dan Bungkil Kelapa Melalui Proses Fermentasi Bakteri Probiotik Terhadap Pola Pertumbuhan dan Produksi Biomassa Daphnia Sp. Journal of Aquaculture Management and Technology., 3(2): 44-52.

Kusuma, Maria E. 2012. Pengaruh Takaran Pupuk Kandang Kotoran Burung Puyuh Terhadap Pertumbuhan dan Hasil Tanaman Sawi Putih. Fakultas Peternakan Universitas Kristen
Palangka Raya. Jurnal Ilmu Hewani Tropika 1 (1): 7-11

Mokoginta, I., D. Jusadi, dan T.L. Pelawi. 2003. Pengaruh Pemberian Daphnia sp. yang Diperkaya dengan Sumber Lemak yang Berbeda terhadap Kelangsungan Hidup dan Pertumbuhan Larva Ikan Nila (Oreochromis niloticus). Jurusan Budidaya Perairan, Fakultas Perikanan dan Ilmu Kelautan. Institut Pertanian Bogor. Jurnal Akuakultur Indonesia 2 (1): 7-11

Mubarak, A.S., D.T.R. Tias dan L. Sulmartiwi. 2009. Pemberian Dolomit Pada Kultur Daphnia sp. Sistem Daily Feeding Pada Populasi Daphnia sp. dan Kestabilan Kualitas Air. Jurnal Ilmiah Perikanan 1 (1) : $67-72$.

Mulia, D.S.,Eka Y., Heri M., Cahyono P. 2015. Peningkatan Kualitas Ampas Tahu Sebagai Bahan Baku Pakan Ikan Dengan Fermentasi Rhizopus oligosporus. Fakultas Keguruan dan Ilmu Pendidikan, Universitas Muhammadiyah. Purwokerto.Saintek 12 (1) : 10-19

Pamukas, N. R. 2011. Perkembangan Kelimpahan Fitoplankton Dengan Pemberian Pupuk Organik Cair. Fakultas Perikanan dan Ilmu Kelautan. Universitas Riau. Berkala Perikanan Terubuk 39 (1) 79-90

Pangkey, H. 2009. Daphnia dan Penggunaannya. Jurnal Perikanan dan Kelautan UNSRAT. Manado., 5(3): 33-36.

Pratiwi, A. R., Dahrul S., Linawati H., Lily M. G. P., Maggy T. S. 2009. Fatty Acid Synthesis by Indonesian Marine Diatom, Chaetoceros gracilis. Department of Food Technology, Soegijapranata Catholic University. Semarang. HAYATI Journal Biosciences 16 (4) : 151-156

Umainana, M.R., A.S, Mubarak dan E.D, Masitah. 2012. Pengaruh Konsentrasi Pupuk Daun Turi Putih (Sesbaniagrandiflora) terhadap Pertumbuhan Chlorella sp. Jurnal Perikanan dan Ilmu Kelautan, $13 \mathrm{hlm}$.

Utarini, Diana Retna S.R., Casmudi, Kusbiyanto. 2012. Pertumbuhan Populasi Daphnia sp. Pada Media Kombinasi Kotoran Puyuh dan Ayam Dengan Padat Tebar Awal Berbeda. Prosiding Seminar Nasional Pengembangan 
Sumber Daya Pedesaan dan Kearifan Berkelanjutan II. Fakultas Biologi Universitas Jendral Soedirman. Purwokerto, 46-52 hlm

Utomo N.B.P., A. Rosmawati, I. Mokoginta. 2009. Pengaruh Pemberian Kadar Asam Lemak N6 berbeda Pada Kadar Asam Lemak N-3 tetap (\%) dalam Pakan Terhadap Penampilan Reproduksi Ikan Zebra. Fakultas Perikanan dan Ilmu Kelautan. Institut Pertanian Bogor. Jurnal Akuakultur Indonesia 5 (1) : 51-56

Wibowo, A. 2014. Pemanfaatan Kompos Kulit Kakao (Theobroma cacao) Untuk Budidaya Daphnia sp.. e-Jurnal Rekayasa dan Teknologi Budidaya Perairan. 2 (2): 227-232

Widjastuti, T. dan Endang S. 2007. Pemanfaatan Tepung Limbah Roti Dalam Ransum Ayam Broiler dan Implikasinya Terhadap Efisiensi
Ransum. Prosiding Seminar Nasional Fakultas Perternakan UNPAD. ISBN : 978602-95808-0-8.

Yusefi, Vitriyone. 2011. Karakteristik Asam Lemak Kerang Bulu (Anadara antiquata). [Skripsi]. Fakultas Perikanan dan Ilmu Kelautan. Institut Pertanian Bogor

Zahidah, 2012. Pertumbuhan Populasi Daphnia sp. Yang Diberi Pupuk Limbah Budidaya Karamba Jaraing Apung (KJA) di Waduk Cirata Yang Telah di Fermentasi EM4. Jurnal Akuatika. III(1): 84-94. 